MARIA TKOCZ, JAKUB ŻYDZIK

Uniwersytet Śląski

\title{
Przejawy społeczeństwa informacyjnego w województwie śląskim
}

Pojęcie „społeczeństwo informacyjne” jest ostatnio modnym i nośnym terminem. Świadczą o tym liczne publikacje prasowe i naukowe poświęcone sprawom współczesnego świata. Nie wyjaśniają one jednak w pełni zakresu pojęcia „społeczeństwo informacyjne”. Mimo istnienia różnorodnych definicji, żadna nie jest powszechnie akceptowana. Intuicyjnie, przeciętny człowiek określi je jako takie społeczeństwo, gdzie używa się powszechnie komputerów i technik z nimi związanych.

Pierwsze wzmianki na temat społeczeństwa informacyjnego pojawiły się w połowie lat sześćdziesiątych w Japonii. Termin ,johoka shakai”, oznaczający społeczeństwo komunikujące się poprzez komputer lub po prostu społeczeństwo informacyjne, został użyty po raz pierwszy w 1963 roku przez Tadao Umesao w artykule na temat ewolucyjnej teorii społeczeństwa opartego na informacji.

Według Urzędu Komitetu Integracji Europejskiej społeczeństwo informacyjne to nowy typ społeczeństwa, ukształtowany w krajach wyróżniających się szybkim tempem rozwoju nowoczesnych technologii teleinformatycznych. Podstawowymi wyznacznikami, które muszą być spełnione, aby dane społeczeństwo można było uznać za informacyjne, jest rozbudowana sieć telekomunikacyjna, obejmująca swoim zasięgiem wszystkich obywateli oraz rozbudowane systemy informatyczne dostępne publicznie. Ważnym aspektem jest również kształcenie społeczeństwa w kierunku dalszego rozwoju, tak aby wszyscy mogli w pełni wykorzystać możliwości, jakie dają środki masowej komunikacji i informacji. Za główne cele społeczeństwa informacyjnego uznano: Internet jako środek komunikacji obywatelskiej i informacji publicznej, powszechny dostęp do informacji oraz edukację.

Zdaniem wielu badaczy proces przejścia od społeczeństwa industrialnego do społeczeństwa informacyjnego będzie odbywał się stopniowo. Każda cywilizacja nie jest całkowicie i od razu zastępowana przez następna, ale najpierw jest częściowo i stopniowo modyfikowana i w postaci zmodyfikowanej może istnieć przez długi okres czasu (Zacher 2004).

W świetle przedstawionych poglądów celem publikacji jest próba odpowiedzi na pytanie, czy społeczeństwo województwa śląskiego petryfikuje się jako społeczeństwo przemysłowe, czy też ewoluuje w stronę społeczeństwa informacyjnego. Jako materiały źródłowe posłużyły dane statystyczne publikowane przez Urząd Statystyczny w Katowicach.

$\mathrm{Na}$ podstawie tradycyjnych mierników mówiących o poziomie uprzemysłowienia województwo śląskie pozostaje na etapie cywilizacji przemysłowej. Spośród wszystkich województw w Polsce wyróżnia się najwyższą liczbą zatrudnionych w przemyśle, która 
w 2006 roku wyniosła 458,0 tys., co stanowiło 16,9\% ogółu zatrudnionych w przemyśle Polski. W przeliczeniu na 1000 mieszkańców był to wskaźnik 98, stawiający opisywany region na pierwszym miejscu w kraju. Województwo śląskie należy również do czołówki (drugie miejsce po mazowieckim) pod względem wielkości produkcji sprzedanej przemysłu, która w 2006 roku wyniosła 140,5 mld zł, co stanowiło 17,9\% produkcji przemysłowej Polski, a także pod względem wielkości nakładów inwestycyjnych na przemysł, których wartość w 2006 roku wyniosła 9508,4 mln zł, co stanowiło 18,0\% nakładów na przemysł w Polsce (pierwsze miejsce wśród województw). Również najwyższa była wartość brutto środków trwałych w przemyśle województwa śląskiego, stanowiąca 18,0\% ogólnej wartości brutto środków trwałych przemysłu Polski. Przedstawione powyżej mierniki wskazują, że województwo śląskie należy do najsilniej uprzemysłowionych regionów w Polsce. Dominującymi gałęziami przemysłu regionu w ciągu 50 lat po II wojnie światowej było górnictwo węgla kamiennego i hutnictwo, które utrwalały pozycję województwa jako regionu silnie związanego z cywilizacją przemysłową Dla potrzeb tych gałęzi rozwinięty był system szkolnictwa zawodowego, a mieszkańcy województwa charakteryzowali się ogólnie niskim poziomem wykształcenia, ponieważ aż 70\% osób (1988) posiadało wykształcenie podstawowe i zasadnicze zawodowe (ryc. 1).

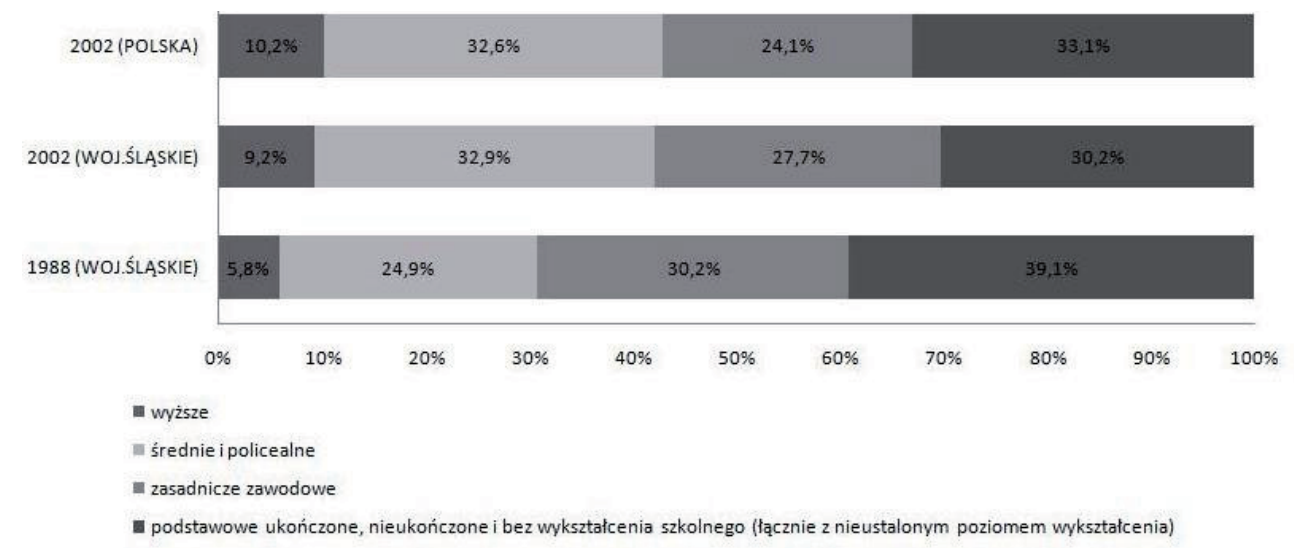

Ryc. 1. Ludność według poziomu wykształcenia

Źródło: Narodowy Spis Powszechny Ludności i Mieszkań, 2002, Urząd Statystyczny w Katowicach

Pierwszym przejawem dokonujących się zmian był wzrost poziomu wykształcenia mieszkańców województwa. W okresie międzyspisowym 1988-2002 odsetek osób z wykształceniem wyższym wzrósł z 5,8\% do 9,2\%, jednak pozostał niższy w porównaniu z odpowiednim odsetkiem w skali kraju, który wyniósł 10,2\% (ryc. 1). Odsetek osób z innych grup wykształcenia był wyższy od średnich dla Polski. Cechą wyróżniająca województwo śląskie jest wyższy poziom wykształcenia mieszkańców wsi, wyrażający się wyższym odsetkiem osób na wszystkich poziomach wykształcenia w porównaniu z odpowiednim odsetkiem dla obszarów wiejskich Polski. Pozytywnym zjawiskiem był również wzrost poziomu wykształcenia - odsetek grup o najniższym dotychczas wykształceniu podstawowym obniżył się aż o $8,9 \%$ (ryc. 1), a także wzrost populacji osób z średnim i policealnym wykształceniem o $8,0 \%$. A zatem pierwszy pozytywny symptom kształtowania się społeczeństwa informa- 
cyjnego w postaci wzrostu ogólnego poziomu wykształcenia można zaobserwować w województwie śląskim.

Czynnikiem istotnych zmian w strukturze wykształcenia województwa był rozwój szkolnictwa wyższego. W roku akademickim 1990/91 funkcjonowało w województwie 10 szkół wyższych, natomiast obecnie jest ich 44 (w tym 1 uniwersytet, 3 wyższe szkoły techniczne, 15 szkół wyższych ekonomicznych, 2 wyższe szkoły pedagogiczne, 1 uniwersytet medyczny, 1 akademia wychowania fizycznego, 2 wyższe szkoły artystyczne, 16 wyższych szkół zawodowych, 1 wyższa szkoła teologiczna, 2 szkoły wyższe o profilu uniwersyteckim). Stanowiło to 9,9\% szkół wyższych w kraju i tym samym województwo śląskie znajdowało się na drugim miejscu pod względem liczby szkół wyższych w Polsce. Kształciły one w 2006 r. 203238 osób (10,5\% studentów w Polsce). Pod względem liczby studentów województwo śląskie zajmowało również drugie miejsce. Liczba studentów wzrosła w latach 1990-2006 ponadsześciokrotnie, z 32,4 tys. w roku akademickim 1990/91 do 203,2 tys. w roku 2006/07.

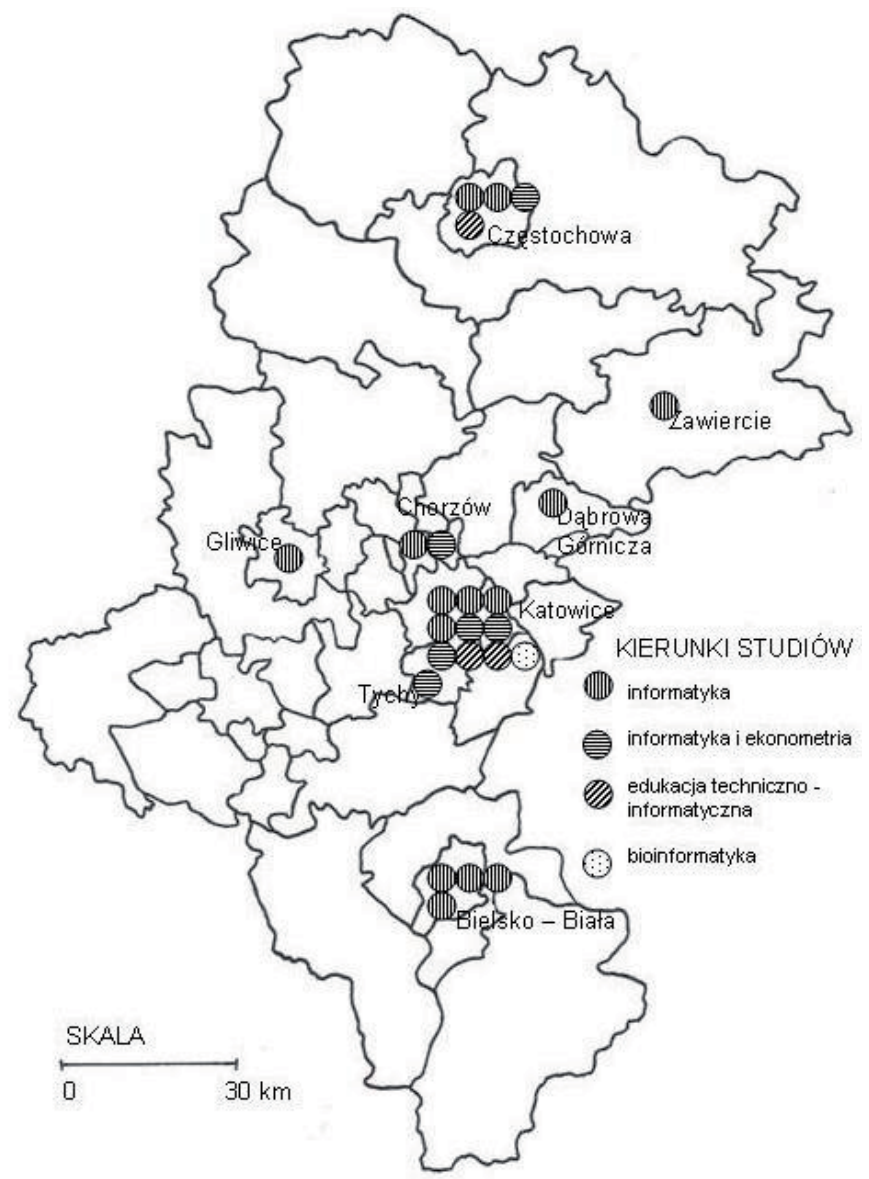

Ryc. 2. Przestrzenne rozmieszczenie szkół wyższych kształcących w zakresie nauk techniczno-informatycznych 
Drugim symptomem zmian są nowe kierunki studiów odpowiadające potrzebom nowej cywilizacji. Takim kierunkiem jest informatyka, odbierana w świadomości społeczeństwa jako zawód przyszłościowy, w zakresie której kształcą się studenci na 5 publicznych uczelniach wyższych (Akademia Techniczno-Humanistyczna w Bielsku-Białej, Politechnika Częstochowska i Akademia Polonijna w Częstochowie, Politechnika Śląska w Gliwicach i Uniwersytet Śląski w Katowicach) oraz w 9 prywatnych uczelniach na poziomie licencjatu. W zakresie informatyki i ekonometrii czerpią wiedzę studenci Politechniki Częstochowskiej i Akademii Ekonomicznej w Katowicach oraz 4 szkół prywatnych. Spośród wyżej wymienionych uczelni jedynie Akademia Ekonomiczna oferuje studia na poziomie magisterskim. Oprócz informatyki szkoły wyższe w województwie śląskim kształcą w zakresie edukacji techniczno-informatycznej (2 szkoły publiczne i 1 prywatna), a Śląski Uniwersytet Medyczny kształci słuchaczy zakresie bioinformatyki (ryc. 2). Z innych kierunków można wymienić automatykę i robotykę (Politechnika Śląska oraz Akademia Techniczno-Humanistyczna) a także elektronikę (2 szkoły publiczne i 1 prywatna).

Ze względu na fakt, że GUS od 2003 roku zrezygnował z publikowania danych na temat liczby studentów i absolwentów według poszczególnych kierunków studiów poprzestając na podgrupach można stwierdzić, że odsetek studentów kształcących się na kierunkach techniczno-informatycznych wyniósł 19,3\% i w roku akademickim 2002/03 i wzrósł z 27,3 tys. w roku akademickim 1998/99 do 37,5 tys. w roku 2002/03, czyli o 37\% (tab. 1). W tym samym czasie liczba osób studiujących kierunki związane z tradycyjnymi dziedzinami gospodarki województwa, czyli górnictwem i hutnictwem wzrosła z 1,8 tys. do 3,0 tys., czyli o $68 \%$, a jej relatywny udział w ogólnej populacji studentów obniżył się z $5,6 \%$ do $3,3 \%$.

Tab. 1. Studenci według wybranych grup kierunków studiów

\begin{tabular}{|l|r|r|r|r|c|}
\hline \multicolumn{1}{|c|}{ Grupy kierunków studiów } & $1998 / 99$ & $1999 / 00$ & $2000 / 01$ & $2002 / 03$ & $\begin{array}{c}\text { Zmiana liczby } \\
\text { studentów } \\
1999-100\end{array}$ \\
\hline artystyczna & 1060 & 1169 & 1272 & 1324 & $125 \%$ \\
\hline biznesu i administracji & 43450 & 52911 & 61588 & 65471 & $151 \%$ \\
\hline humanistyczna & 10149 & 12140 & 12775 & 12457 & $123 \%$ \\
\hline inżyniersko-techniczna & 25190 & 26947 & 29110 & 32471 & $129 \%$ \\
\hline matematyka, programy komputerowe & 2157 & 3453 & 4273 & 5021 & $233 \%$ \\
\hline nauki przyrodnicze & 2589 & 3730 & 3746 & 3841 & $148 \%$ \\
\hline nauki społeczne & 11167 & 13180 & 14884 & 15014 & $134 \%$ \\
\hline pedagogika i kształcenie nauczycieli & 22117 & 20706 & 21591 & 21415 & $97 \%$ \\
\hline transport i komunikacja & 1097 & 1127 & 1342 & 1387 & $126 \%$ \\
\hline
\end{tabular}

Źródło: opracowanie własne na podstawie Rocznika Statystycznego Województwa Śląskiego

Wzrost zainteresowania studiami informatycznymi oraz rozszerzenie oferty szkół wyższych w tym zakresie jest kolejną odznaką zmian zachodzących w społeczeństwie województwa śląskiego. 
Zdaniem D. Bella (1973) jedną z cech społeczeństwa informacyjnego jest dominacja sektora usług w gospodarce. Od momentu powstania województwa, tj. od roku 1999, sektor usług dominuje w strukturze sektorowej gospodarki wykazując jednocześnie stałą tendencję wzrostową. W 2006 r. udział tego sektora wyniósł 57,4\% i był wyższy w porównaniu z wartościami średnimi dla Polski (54,9\%). Według opinii F. Kłosowskiego (2008) usługi informacyjne związane $\mathrm{z}$ tworzeniem, przetwarzaniem, przesyłaniem i gromadzeniem informacji wykazują w woj. śląskim wyższą dynamikę przyrostu pracujących w porównaniu z pozostałymi usługami. W okresie 2000-2006 ogólna liczba pracujących w dziale informatyka, wchodzącym w skład sekcji obsługa nieruchomości i firm, wzrosła z 4528 do 5902 osób, czyli o 30,5\%. W tym samym czasie liczba pracujących w tym dziale w Polsce wykazała większą dynamikę, wzrosła bowiem o 49,3\%. O ile w 2000 roku na 1000 pracujących ogółem wskaźnik pracujących w informatyce w województwie śląskim był wyższy $(3,9 \%)$ od odpowiedniego wskaźnika dla Polski (3,2\%), to w 2006 roku relacje były odwrotne, chociaż różnice nie były duże (śląskie - 5,6\%, Polska - 5,7\%). Wskazuje to na wolniejsze tempo rozwoju pracujących w działalności informatyka na obszarze województwa śląskiego (ryc. 3).

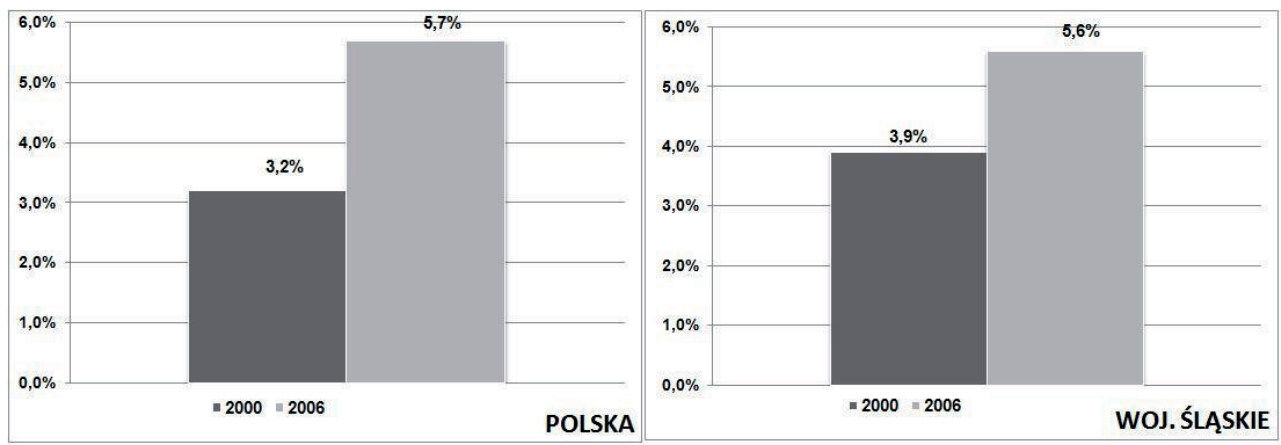

Ryc. 3. Pracujący w dziale „Informatyka” na 1000 pracujących ogółem

Źródło: Rocznik Statystyczny Województwa Śląskiego

Jedną z głównych cech społeczeństwa informacyjnego jest rozbudowana sieć telekomunikacyjna oraz rozbudowane systemy informacyjne dostępne publicznie. W tym zakresie miernikiem może być dostępność do Internetu. Pod tym względem sytuacja w województwie śląskim kształtuje się lepiej w porównaniu z wartościami ogólnopolskimi. Z Internetu korzysta obecnie 33,9\% gospodarstw domowych w województwie i $28,4 \%$ w Polsce. W krajach Unii Europejskiej powyższy wskaźnik w porównywalnym roku 2006 wyniósł 49,0\%.

Województwo śląskie ma również nieco wyższe wskaźniki w porównaniu z wartościami średnimi dla Polski w zakresie posiadania przez mieszkańców komputera osobistego (śląskie $-46,0 \%$, Polska - 43,7\%) oraz telefonu komórkowego (śląskie - 74,4\%, Polska - 73,1\%). Pewną miarą publicznej dostępności do sieci może być dostęp do Internetu w szkołach, zwłaszcza podstawowych i gimnazjach. W Polsce 92,7\% szkół podstawowych wyposażonych jest w komputery, z czego 57,7\% posiada dostęp do Internetu. W województwie śląskim odsetek szkół podstawowych wyposażonych w komputer jest o 0,1 punktu procentowego wyższy (92,8\%), natomiast dostęp do Internetu posiada $62,7 \%$ szkół podstawowych W przypadku gimnazjów odpowiednie wartości wynoszą dla Polski 79,0\%, a dostęp 
do Internetu ma 73,8\% tych szkół, natomiast w województwie śląskim 82,8\% gimnazjów wyposażonych jest w komputery, zaś $75,4 \%$ posiada dostęp do Internetu.

Symptomy zmian zmierzających w stronę społeczeństwa informacyjnego można zaobserwować także w przemyśle, analizując nakłady na działalność innowacyjną. Najwięcej środków na działalność innowacyjną w przemyśle wynoszącą 645,6 mln zł, czyli 18,1\% ogółu środków na działalność innowacyjną w przemyśle województwa śląskiego, wydatkował dział produkcja pojazdów samochodowych, przyczep i naczep. Dział ten wydał również najwięcej środków na działalność badawczo-rozwojową $(21,8 \%)$ i na oprogramowanie $(18,8 \%)$. Kolejne miejsca pod względem wydatkowania środków na działalność innowacyjną zajęły działy: produkcja wyrobów gumowych i z tworzyw sztucznych (blisko 8\%), produkcja artykułów spożywczych i napojów $(5,7 \%)$ oraz produkcja wyrobów z metali $(5,4 \%)$. Dla porównania można dodać, że tradycyjne górnictwo przeznaczyło na działalność innowacyjną $157,4 \mathrm{mln}$ zł (4,4\%), w tym na działalność badawczo-rozwojową 7,3 $\mathrm{mln}$ zł (2,8\%) oraz oprogramowanie $2,7 \mathrm{mln}$ zł. (3,5\%). W dziale produkcja samochodów zainstalowanych było najwięcej komputerów do sterowania procesami technologicznymi, bo 1041 na ogólna liczbę 5203 w przemyśle województwa śląskiego, natomiast górnictwo posiadało jedynie 226 sztuk. Należy zauważyć, iż począwszy od 2000 roku liczba komputerów sterujących procesami produkcji wzrosła ponaddwukrotnie. Przedstawione powyżej dane liczbowe wskazują na dynamiczny proces modernizacji odbywający się w przemyśle, który polega na coraz szerszym zastosowaniu narzędzi cywilizacji informacyjnej. Proces ten wpłynął również na zmiany w strukturze przemysłu woj. śląskiego, w którym pierwsze miejsce w produkcji sprzedanej zajęła produkcja pojazdów samochodowych, przyczep i naczep ( Pukowska-Mitka, Tkocz 2008).

Tab. 2. Parki przemysłowe i technologiczne funkcjonujące na obszarze województwa śląskiego

\begin{tabular}{|l|l|c|c|}
\hline \multicolumn{1}{|c|}{ Nazwa parku } & \multicolumn{1}{|c|}{ Położenie } & $\begin{array}{c}\text { Rok } \\
\text { powstania }\end{array}$ & $\begin{array}{c}\text { Pow. } \\
\text { Parku }\end{array}$ \\
\hline Bytomski Park Przemysłowy (BPP) & Bytom & 2004 & 276 ha \\
\hline Częstochowski Park Przemysłowy & Częstochowa & 2003 & bd. \\
\hline Goleszowski Park Przemysłowy & Goleszów & 2003 & 11 ha \\
\hline Górnośląski Park Przemysłowy & Katowice & 2005 & b.d \\
\hline Jaworznicki Park Przemysłowy & Jaworzno & 2004 & 158 ha \\
\hline Park Naukowo-Technologiczny Technopark Gliwice & Gliwice & 2004 & bd. \\
\hline Park Przemysłowy Stara Huta & Gliwice & 2006 & 14,5 ha \\
\hline Piekarski Park Przemysłowy & Piekary Śląskie & 2006 & 130 ha \\
\hline Rybnicki Inkubator Technologiczny (RIT) & Rybnik & 2005 & 0,9 ha \\
\hline Sosnowiecki Park naukowo-Technologiczny (SPNT) & Sosnowiec & 2003 & 11,9 ha \\
\hline Śląski Park Przemysłowy & $\begin{array}{l}\text { Ruda Śląska, } \\
\text { Świętochłowice }\end{array}$ & 2003 & 1090 ha \\
\hline Żorski Park Przemysłowy (ŻPP) & Żory & 2004 & 8,6 ha \\
\hline
\end{tabular}

Źródło: http://www.rcoi.pl 
W fazie rozwoju społeczeństwa informacyjnego pojawiają się nowe instrumenty ekonomiczne pobudzające procesy kształtowania gospodarki opartej na wiedzy. Należą do nich m.in. parki technologiczne i przemysłowe, których celem jest stworzenie warunków do rozwoju wysokich technologii i transferu wiedzy z uczelni wyższych do biznesu oraz budowanie konkurencyjności przemysłu. Parki takie powstały również na obszarze województwa śląskiego (tab. 2). Są to tereny przygotowane pod kątem funkcjonowania innowacyjnych podmiotów gospodarczych. Parki przemysłowe obejmują zazwyczaj zespół nieruchomości wraz z istniejącą infrastrukturą pozostałą po restrukturyzowanych lub likwidowanych przedsiębiorstwach. Natomiast parki technologiczne, zwane również technoparkami, tworzą zespoły nieruchomości utworzonych w celu dokonywania przepływu wiedzy i technologii pomiędzy jednostki naukowymi a przedsiębiorcami (Papińska-Kacperek 2008)

W konkluzji można stwierdzić, że w województwie śląskim zaobserwowano pewne symptomy wskazujące na rozwój społeczeństwa informacyjnego. Należą do nich:

- wzrost poziomu wykształcenia mieszkańców,

- rozwój nowych kierunków studiów związanych z informatyką i wzrost liczby studentów w tym zakresie,

- wzrost liczby pracujących w dziale informatyka,

- wysoki poziom dostępności Internetu,

- wzrost nakładów na działalność innowacyjną w przemyśle oraz dynamiczny rozwój komputeryzacji procesów produkcyjnych.

Przedstawione powyżej aspekty wskazują, że w województwie śląskim podobnie jak na obszarze całego kraju zaczynają pojawiać się pewne elementy społeczeństwa informacyjnego, jednak ich pełne wykształcenie na chwilę obecną wydaje się być odległe.

\section{Literatura}

Casey M., 2001, Europejska polityka informacyjna. Wyzwania i perspektywy dla administracji publicznej, Międzynarodowe Centrum Zarządzania Informacją Uniwersytetu M. Kopernika, Toruń.

Juszczyk S., 2000, Człowiek w świecie elektronicznych mediów - szanse i zagrożenia, Wydawnictwo Uniwersytetu Śląskiego, Katowice.

Kłosowski F., 2008, Ustugi, [w:] M. Tkocz red., Województwo ślaskie. Zarys geograficzno-ekonomicz$n y$, Wydział Nauk o Ziemi UŚ, Sosnowiec.

Papińska-Kacperek J. red., 2008, Społeczeństwo informacyjne, Wydawnictwo Naukowe PWN, Warszawa.

Pukowska-Mitka M., Tkocz M., 2008, Przemyst, [w:] M. Tkocz red., Województwo ślaskie. Zarys geograficzno-ekonomiczny, Wydział Nauk o Ziemi UŚ, Sosnowiec.

Raport 1 Kongresu Informatyki Polskiej, Poznań 1994 wg http://www.kongres.org.pl

Rocznik Statystyczny Województwa Śląskiego 1999-2007, Urząd Statystyczny, Katowice.

Rocznik Statystyczny Województwa Katowickiego 1991-1998, Wojewódzki Urząd Statystyczny, Katowice

Zacher L.W., 2006, Społeczeństwo postinformacyjne w kontekście ewolucji społeczeństw $i$ wizji przyszłości, [w:] Społeczeństwo informacyjne, Wydawnictwo Uniwersytetu Jagiellońskiego, Kraków.

http://www.kierunkistudiow.pl

http://www.silesia-region.pl

http://www.rcoi.pl 


\section{Symptoms of development of an information society in the Silesian Voivodship}

The Silesian Voivodship is one of the most industrialised ones in Poland. It can be characterised by the highest number of employees in industry, which was equal to 458,000 in 2006 , i.e. $16.9 \%$ of the total number of employees in industry in Poland. When calculated per 1000 inhabitants, the coefficient is equal to 98 and it gives the voivodship the first place in the country. The Silesian Voivodship is also close to the top as far as sold industrial production is concerned (the second place after the Mazowieckie Voivodship), which was $140,500,000,000$ PLN in 2006, making $17.9 \%$ of the total industrial production in Poland, and also in the field of industrial investments, the value of which was equal to 9,500,000,000 PLN, making $18 \%$ of all investments in industry in Poland (the first place among all voivodships). Also the value of fixed asset in industry, being equal to $18.0 \%$ of the total value of the fixed asset in industry in Poland is the highest in the Silesian Voivodship. The presented factors prove a dominating role of industry in the voivodship economy and the industrial character of its inhabitants.

The process of transformation from an industrial to an information society develops gradually. A civilisation is never totally and immediately replaced by another, but it is successively modified and it can exist in that modified form for a long time. According to the above assumption, the goal of the paper is to present selected aspects of development of the information society in the Silesian Voivodship.

prof. UŚ dr hab. Maria Tkocz, mgr Jakub Żydzik

Uniwersytet Śląski

e-mail: m.t.tkocz@interia.pl 